\title{
Analisis Implementasi Pola Pengelolaan Keuangan Badan Layanan Umum Daerah pada Rumah Sakit Umum Daerah Dr. RM. Djoelham Binjai
}

\section{Analysis of Implementation of The Financial Management Pattern of The Regional Public Services Agency in the Regional Public Hospital Dr. RM. Djoelham Binjai}

\author{
Bambang Azis Silalahi, Marlon Sihombing \& Isnaini* \\ ${ }^{1}$ Program Studi Magister Administrasi Publik, Universitas Medan Area, Indonesia \\ 2 Fakultas Ilmu Sosial dan Ilmu Politik, Universitas Sumatera Utara, Indonesia \\ ${ }^{3}$ Fakultas Hukum, Universitas Medan Area, Indonesia
}

Diterima: 09 Juni 2022; Disetujui: 15 Desember 2021; Dipublish: 01 Januari 2022

\begin{abstract}
Abstrak
Pemerintahan telah meluncurkan program Badan Layanan Umum/Badan Layanan Umum Daerah (BLU/BLUD) dengan diterbitkannya Peraturan Pemerintah Nomor 23 tahun 2005. PP 23 Tahun 2005 tentang Pengelolaan Keuangan Badan Layanan Umum yang pada intinya menjelaskan, Badan Layanan Umum tidak hanya sebagai bentuk baru dalam pengelolaan keuangan Negara namun juga sebagai paradigma baru bagi manajemen pelayanan sektor publik. Tujuan dari penelitian ini adalah untuk mengetahui dan menganalisis, bagaimana Implementasi kebijakan PPK-BLUD di RSUD Dr. RM Djoelham Binjai dalam hal meningkatkan kualitas dan mutu pelayanan publik khususnya pelayanan kesehatan kepada masyarakat Kota Binjai. Metode yang digunakan pada penelitian ini adalah kualitatif deskriptif dengan menggunakan teori Merille S. Grindle dimana ada beberapa variabel yang menentukan keefektifan implementasi kebijakan Dari hasil penelitian dapat dilihat bahwa setelah penerapan PPK-BLUD di RSUD Dr. RM. Djoelham Binjai, terdapat perubahan dimana sebelumnya proses pengelolaan anggaran, keuangan, dan pelaporan yang selama ini murni harus berdasarkan peraturan keuangan dengan mekanisme APBD. Namun dengan penerapan PPK-BLUD, seluruh pendapatan yang peroleh RSUD Djoelham dapat langsung dikelola dan dipergunakan untuk kebutuhan dan keperluan RSUD. Sehingga diharapkan dapat memperingkas birokrasi khususnya keuangan sehingga pada akhirnya dapat meningkatkan mutu pelayanan Rumah Sakit. Dalam pelaksanannya terdapat beberapa kendala yang dihadapi terutama pemahaman bagian dan bidang lain tentang PPK-BLUD yang ada di RSUD Djoelham Binjai sehingga dibutuhkan koordinasi yang baik antar bagian dan bidang. Kata Kunci: Rumah Sakit, implementasi, Pola Pengelolaan Keuangan; Badan Layanan Umum Daerah
\end{abstract}

\section{Abstract}

The government has launched the Public Service Agency / Regional Public Service Agency (BLU / BLUD) program with the issuance of Government Regulation Number 23 of 2005. PP 23 of 2005 concerning Financial Management of Public service agency which basically explains, Public service agency are not only a new form in management of state finances but also as a new paradigm for public sector service management. The purpose of this study was to determine and analyze how the implementation of PPK-BLUD policies in RSUD Dr. RM Djoelham Binjai in terms of improving the quality and quality of public services, especially health services to the people of Binjai City. The method used in this research is descriptive qualitative using the Merille S. Grindle theory where there are several variables that determine the effectiveness of policy implementation. From the research results it can be seen that after the implementation of PPK-BLUD in Dr. RM. Djoelham Binjai, there was a change where previously the budget management, finance and reporting processes, which had been purely based on financial regulations with the APBD mechanism. However, with the implementation of PPK-BLUD, all the income that the RSUD Dr. RM. Djoelham receives can be directly managed and used for the needs and needs of the RSUD. So it is hoped that it can simplify the bureaucracy, especially finance, so that in the end it can improve the quality of hospital services. In its implementation, there are several obstacles faced, especially the understanding of other sections and fields of PPK-BLUD in RSUD Dr. RM. Djoelham Binjai so that good coordination between divisions and fields is needed.

Keywords: Hospital; implementation; The Financial Management Pattern of The Regional; Public Services Agency

How to cite: Silalahi, B.A. Sihombing, M. \& Isnaini, (2021) Analisis Implementasi Pola Pengelolaan Keuangan Badan Layanan Umum Daerah (Blud) Pada Rumah Sakit Umum Daerah (RSUD) Dr. Rm. Djoelham Binjai. PERSPEKTIF, 11 (1): 160-168.

\footnotetext{
*Corresponding author:

E-mail: isnaini@staff.uma.ac.id
}

ISSN 2085-0328 (Print) 
PERSPEKTIF, 11 (1) (2022): 160-168

ISSN 2541-5913 (online) 



\section{PENDAHULUAN}

Wacana Pemerintah untuk merubah paradigma baru manajemen pemerintahan telah dilakukan di Indonesia dengan program Badan Layanan Umum/Badan Layanan Umum Daerah (BLU/BLUD) dengan diterbitkannya Peraturan Pemerintah Nomor 23 tahun 2005. Penjelasan umum PP 23 Tahun 2005 tentang Pengelolaan Keuangan Badan Layanan Umum yang pada intinya menjelaskan, Badan Layanan Umum tidak hanya sebagai bentuk baru dalam pengelolaan keuangan Negara namun juga sebagai paradigma baru bagi manajemen pelayanan sektor publik.

Pelayanan fasilitas publik khususnya pelayanan rumah sakit di Indonesia masih belum memuaskan harapan publik, hal ini disebabkan pelayanan publik khususnya rumah sakit di Indonesia masih identik dengan ketidakpastian baik dalam hal biaya, waktu dan prosedur. Sudah lama masyarakat mengeluhkan penyelenggaraan layanan publik yang dinilai sangat jauh dari harapan (Dwiyanto, 2018). Oleh karena itu, ini menjadi pekerjaan rumah bagi pemerintah untuk meningkatkan penyelenggaraan pelayanan publik lebih baik lagi

Sebagai salah satu contoh masih rendahnya mutu pelayanan rumah sakit dapat dilihat di catatan Ombudsman Perwakilan Sumatera Barat, pada tahun 2019, di bidang kesehatan terdapat tiga laporan yang terkait dengan layanan Puskesmas, tiga laporan terkait dengan layanan RSUD, dan lima laporan yang terkait dengan layanan RSUP M. Djamil.

Institusi Pemerintah diharapkan untuk melepaskan diri dari birokrasi lama, dengan mengajak organisasi dan pegawai agar lebih fleksibel, dan menetapkan tujuan, serta target organisasi secara lebih jelas sehingga memungkinkan pengukuran hasil (Hood dalam Saggaf dkk, 2018).

Penilaian hasil kinerja sebuah instansi baik keuangan maupun non-keuangan akan lebih mudah untuk dinilai kalau sebuah organisasi atau institusi tersebut memiliki tujuan dan sasaran yang jelas. Tujuan dan sasaran inilah yang menjadi tolak ukur sukses atau tidaknya pengelolaan sebuah institusi. Semua yang dicanangkan oleh pemerintah pada dasarnya untuk mewujudkan pola yang efektif dan efisien pada institusi-institusi yang ada

\section{METODE PENELITIAN}

Dalam penelitian ini, peneliti akan menggunakan metodologi penelitian deskriptif kualitatif. Menurut Bogman dan Taylor yang dikutip Moleong (1993) didefinisikan sebagai prosedur penelitian yang menghasilkan data deskriptif berupa kata-kata tertulis/ lisan dari orang-orang dan perilaku yang dapat dicermati.

Penelitian ini akan membahas implementasi kebijakan dengan menggunakan teori yang disampaikan Merille S. Grindle bahwa sebuah Implementasi Kebijakan akan berhasil atau gagal dalam implementasinya dengan menentukan sebelumnya apa saja konten dan konteks kebijakan yang telah dibuat, yaitu konten atau isi kebijakan, dan konteks implementasi kebijakan. Sumber data dalam penelitian ini adalah dengan mengumpulkan data primer dan data sekunder. Teknik yang di lakukan dalam proses pengumpulan data adalah observasi, dokumentasi dan wawancara.

Proses analisis implementasi kebijakan menurut Merille S. Grindle mencakup 2 variabel besar yakni isi kebijakan (content of policy) dan lingkungan implementasi (context of implementation) yang merupakan unsur untuk mempengaruhi kesuksesan dari implementasi suatu kebijakan. Oleh karena itu peneliti akan melakukan analisa dari hasil penelitian yang akan dilakukan seperti yang disajikan. Data yang telah diperoleh baik dari kegiatan dokumentasi, wawancara maupun observasi yang akan disampaikan dengan teknik analisis kualitatif dengan metode deskriptif dan tetap bertumpu pada hasil interpelasi data dan informasi yang sesuai dengan rumusan masalah dalam penelitian ini.

\section{HASIL DAN PEMBAHASAN Implementasi PPK-BLUD}

Dalam mengimplementasikan suatau kebijakan perlu ditentukan variabel- variabel yang terkait dalam proses pelaksanaaan suatu kebijakan tersebut. Berdasarkan variabel variabel tersebut, para pelaksana kebijakan akan mengetahui kesuksesan dan kegagalan dari sebuah kebijakan yang sudah diterapkan, sedang berlangsung atau belum diterapkan. Pada tahapan lainnya akan sangat membantu untuk penyempurnaan dan perbaikan atau evaluasi tahapan implementasi kebijakan dimasa yang datang. 
Isi Kebijakan (Content of Policy), Isi dari sebuah kebijakan merupakan hal yang paling penting untuk diperhatikan dalam membuat sebuah kebijakan, isi kebijakan harus dapat memenuhi kebutuhan kelompok sasaran dari sebuah kebijakan yang dibuat. Keberhasilan implementasi suatu kebijakan akan sangat tergantung dari isi kebijakan tersebut, karena kualitas implementasi kebijakan dinilai sukses dikarenakan telah melewati tahapan penetapan dan penentuan isi kebijakan sebelum suatu kebijakan dilaksanakan.

Teori implementasi kebijakan yang dikemukakan Merille S. Grindle juga menyebutkan bahwa isi kebijakan menjadi hal yang paling utama di tahap implementasiannya, dimana ia mengkatagorikan implementasi kebijakan dapat dilaksanakan jika isi kebijakannnya memiliki enam kriteria yang ia maksudkan yaitu kepentingan-kepentingan terkait, jenis manfaat yang diperoleh, perubahan yang diinginkan, letak pengambilan keputusan, pelaksana program dan sumber-sumber daya yang digunakan untuk melaksanakan kebijakan.

Implementasi PPK-BLUD di RSUD Dr. RM Djoelham Kota Binjai dengan KepentinganKepentingan Terkait

Pada awal implementasi PPK-BLUD di RSUD Dr. RM Djoelham Kota Binjai, para implementor menghadapi berbagai tantangan. Dikarenakan kebijakan baru ini perlu sosialisasi yang memadai kepada seluruh kelompok kepentingan yang terkait dan berkepentingan dengan RSUD Dr. RM. Djoelham Binjai

Berdasarkan hasil wawancara dengan informan kunci yaitu Direktur RSUD Dr. RM. Djoelham Binjai sebagai penanggungjawab rumah sakit yaitu:

"Pada awal pencanangan perencanaan program PPK-BLUD di RSUD Dr. RM Djoelham Kota Binjai ini dibuat untuk menindaklanjuti Peraturan Pemerintah Nomor 23 Tahun 2005 tentang Pengelolaan Badan Layanan Umum dan Permendagri Nomor 61 Tahun 2007 tentang Pedoman Teknis Pengelolaan Keuangan Badan Layanan Umum Daerah. (Informasi dari Direktur RSUD Dr. RM Djoelham Binjai)
Hal senada juga dikemukakan oleh informan lain yaitu wakil direktur keuangan yang menyatakan bahwa :

"Kepentingan untuk implementasi PPKBLUD ini adalah untuk menindaklanjuti hasil rapat dan audiensi direktur RSUD Djoelham kepada Bapak Walikota Binjai mengenai wacana untuk merencanakan implementasi PPK-BLUD di RSUD Djoelham Binjai. Dan pada prinsipnya Bapak Walikota setuju dan meminta Direktur mempersiapkan segala persyaratan yang dibutuhkan untuk penerapan PPK-BLUD di RSUD Djoelham. (Informasi dari Wakil Direktur Keuangan RSUD Djoelham Binjai).

Hal ini dikuatkan oleh PP No. 23 Tahun 2005 bahwa dalam Pola Pengelolaan Keuangan Badan Layanan Umum dapat menerapkan praktek bisnis yang sehat yang berdasarkan kaidah-kaidah manajemen yang baik dalam rangka pemberian layanan yang bermutu dan manajemen berkesinambungan. Hal senada juga dinyatakan oleh Van Meter dan Van Horn (dalam Winarno, 2002:102) bahwa untuk mencapai suatu tujuan harus ditetapkan dalam satu keputusan kebijakan sehingga dapat memberikan perubahan yang diinginkan.

\section{Manfaat Implementasi PPK-BLUD RSUD Dr. RM. Djoelham di Kota Binjai.}

Variabel kedua yang menentukan keberhasilan suatu kebijakan atau program dilaksanakan pada model implementasi kebijakan yang disebutkan oleh Merille S. Grindle, adalah indikator jenis manfaat yang bisa diperoleh. Dari sebuah kebijakan harus bisa ditunjukkan jenis - jenis manfaat yang dapat diraih sebagai efek positif apabila suatu kebijakan tersebut diimplementasikan.

Hal ini seperti hasil wawancara dengan Direktur RSUD sebagai informan kunci, yaitu:

"Manfaat utama dari penerapan PPKBLUD di RS. Djoelham ini adalah kemudahan dan fleksibilitas kita dalam proses penganggaran dan pengelolaan keuangan terutama di awal tahun anggaran. Dengan penerapan PPK-BLUD ini kita dapat langsung bekerja untuk pelayanan kepada masyarakat tanpa harus menunggu proses APBD Kota Binjai yang biasanya belum selesai di awal tahun anggaran. (Informasi dari Direktur RSUD Dr. RM. Djoelham Kota)

Hal ini juga dibenarkan informan lain yaitu kepala bagian anggaran dan program yang menyatakan bahwa : 
"PPK-BLUD sangat memberikan manfaat kepada kami bagian anggaran dan program, terutama soal penganggaran. Walaupun dengan penerapan $P P K-B L U D$ bagian anggaran dan program harus menyiapkan dua dokumen yaitu selain DPA juga harus menyiapkan RBA. Namun dari sisi manfaat sangat memudahkan kami karena fleksibilitas anggaran untuk pendapatan yang diperoleh $R S$ dapat langsung dianggarkan dan dipergunakan langsung untuk kebutuhan rumah sakit".( Informasi dari Kepala Bagian Anggaran dan Program RSUD Dr. RM. Djoelham Kota Binjai)

Di samping hasil wawancara peneliti dengan informan, peneliti juga telah melakukan observasi dan dokumentasi dilapangan, meskipun belum semua ketentuan mengenai PPK-BLUD dapat dilaksanakan, namun dengan keadaan yang sekarang sudah dapat memberi manfaat kepada pihak - pihak yang terkait langsung seperti Bagian Keuangan dan Bagian Anggaran dan Program. Dengan fleksibilitas yang menjadi filosofi utama dari PPK-BLUD, proses perancanaan kegiatan, penganggaran, pengelolaan keuangan dan monitoring laporan keuangan dapat lebih dengan mudah dilaksanakan. Seperti yang diungkapkan juga oleh Charles 0 Jones (dalam Arif Rohman 2009: 101-102) bahwa Implementasi program merupakan langkah - langkah pelaksanaan kegiatan dalam upaya mencapai tujuan dari program itu sendiri.

Keterkaitan Implementasi PPK-BLUD RSUD Dr. RM. Djoelham di Kota Binjai dengan Derajat Perubahan yang Ingin Dicapai.

Dengan diterapkannya PPK-BLUD ini, diharapkan dapat menunjukkan suatu perubahan yang sebelumnya proses pengelolaan anggaran, keuangan, dan pelaporan yang selama ini murni harus berdasarkan peraturan keuangan dengan mekanisme APBD. Namun dengan penerapan PPK-BLUD, seluruh pendapatan yang peroleh RSUD Djoelham dapat langsung dikelola dan dipergunakan untuk kebutuhan dan keperluan RSUD. Sehingga diharapkan dapat memperingkas birokrasi khususnya keuangan sehingga pada akhirnya dapat meningkatkan mutu pelayanan Rumah Sakit.

Hal ini juga sesuai dengan apa yang diungkapkan oleh Wakil Direktur Keuangan yang menjadi informan sewaktu peneliti wawancarai, yaitu pernyataan tentang derajat perubahan yang diinginkan dalam implementasi PPK-BLUD sebagai berikut:

"Dengan Penerapan PPK-BLUD perubahan yang ingin dicapai adalah kcepatan pelayanan dan kemudahan proses penyediaan sarana dan prasarana rumah sakit yang akan digunakan untuk pelayanan kepada masyarakat yang membutuhkan pelayanan kesehatan, dengan adanya aturan yang membolehkan rumah saki mengelola langsung pendapatannya, maka pelayanan akan lebih optimal karena tidak menunggu proses APBD yang cukup memakan waktu". (Informasi dari Wakil Direktur Keuangan)

Akan tetapi, belum semua perubahan yang diharapkan dengan adanya PPK-BLUD dapat tercapai. Hal ini yang disebutkan informan lain yang menyatakan bahwa :

"Ditahapan awal proses perencanaan penganggaran, bagian dan bidang lain yang ada di rumah sakit belum sepenuhnya memahami proses perencanaan yang telah berubah setelah penerapan PPK-BLUD, sehingga dibutuhkan sosialisasi kepad rekan - rekan di bagian dan bidang lain yang ada di rumah sakit. Sehingga mereka dapat memilah - milah mana kebutuhan yang akan di anggarkan dengan sumber dana $A P B D$ dan DAK, mana pula kegiatan yang akan direncanakan dengan sumber dana pendapatan rumah sakit". (Informasi dari Kasubbag Program RSUD Djoelham).

Berdasarkan hasil wawancara yang dilakukan oleh peneliti di atas, peneliti bisa melihat bahwa selama ini perubahan yang ingin dicapai dengan implementasi PPK-BLUD RSUD Dr. RM. Djoelham Binjai ialah agar proses pengelolaan anggaran dan keuangan dapat lebih cepat dan fleksibel sehingga bermuara pada peningkatan mutu pelayanan kepada masyarakat yang lebih baik.

\section{Letak Pengambilan Keputusan dalam Implementasi PPK-BLUD di RSUD Dr. RM. Djoelham Binjai}

Pengambilan keputusan sangat berkaitan erat dengan pihak - pihak berkepentingan dalam implementasi suatu kebijakan, dimana setiap keputusan yang diambil dalam menjalankan suatu kebijakan dan program harus sesuai dengan ketentuan dan peraturan yang telah diputuskan. Sehingga apabila keputusan yang diambil sudah tepat maka para implementor dilapangan tidak akan kesulitan 
dalam melaksanakan keputusan tersebut dan tidak menjadi masalah hukum dikemudian hari. Pernyataan oleh informan kunci diwawancarai peneliti terkait letak pengambilan keputusan, sebagai berikut:

"Setelah mendapat persetujuan dari Bapak Walikota, segera diterbitkan Surat Keputusan Direktur sebagai pengambil keputusan untuk membentuk tim persiapan penerapan PPK-BLUD di RSUD Dr. RM. Djoelham, dalam surat keputusan tersebut telah diuraikan tugas dari tim tersebut. Dengan diterbitkannya SK tersebut, tim yang dibentuk diharapkan dapat segera bekerja mempersiapkan segala persyaratan yang dibutuhkan dalam persiapan penerapan PPK-BLUD". ((Informasi dari Direktur RSUD DR. RM Djoelham Binjai)

Dan informan lain dari Kepala Bagian Anggaran dan Program yang diwawancarai peneliti terkait letak pengambilan keputusan, yaitu:

"Setelah diterapkannya PPK-BLUD di RS Djoelham, biasanya Bapak direktur akan memerintahkan untuk mengadakan rapat mengenai prioritas - prioritas kegiatan yang akan direncanakan untuk dianggarkan pada tahun anggaran berikutnya, dengan mengundang seluruh stake holder yang ada di rumah sakit, setiap bagian dan bidang akan diminta membuat usulan kegiatan pioritas. Selain bagian dan bidang, pihak - pihak lain juga dimintai ususlan prioritas seperti komite medis yang mewadahi para dokter, komite keperawatan dan lain-lain ". (Informasi dari Kepala Bagian Anggaran dan Program RSUD Dr. RM. Djoelham Kota Binjai hasil wawancara pada tanggal 28 januari 2021, Transkrip tentang letak pengambilan keputusan).

Dengan demikian, dari hasil wawancara di atas dapat dilihat bahwa Direktur RSUD Djoelham Binjai sebagai pengambil keputusan dalam pelaksanaan dan pengambilan kebijakan. Direktur, dalam mengambil keputusan selain melibatkan bagian dan bidang yang ada di RSUD Djoelham juga melibatkan komite - komite yang ada. Hal ini sesuai dengan apa yang dikemukakan Thomas R. Dye (dalam Subarsono 2009:2) apapun yang dipilih oleh pemerintah untuk melakukan atau tidak melakukan (public policy whatever government choose to do or not to do). Artinya, segala sesuatu yang dilakukan atau tidak dilakukan tergantung dari keputusan pemerintah.

\section{Pelaksana Program dalam Implementasi PPK-BLUD Di RSUD Dr. RM. Djoelham Kota Binjai}

Keberhasilan sebuah implementasi kebijakan menurut Merille S. Grindle melalui indikator pelaksana program, hal ini dikarenakan bahwa pelaksanaan suatu kebijakan merupakan tolak ukur dan faktor penentu kesuksesan implementasi suatu kebijakan bisa berhasil atau gagal dimplementasikan. Pelaksana program yang ditunjuk harusnya kompeten dan kapabel yang ditentukan dan ditetapkan di awal pembuatan kebijakan. Hal ini dapat diartikan, bahwa pelaksana program inilah yang nantinya akan memberi dan menyediakan pelayanan bagi masyarakat di dalam suatu program yang telah dibuat.

Informan yang diwawancarai oleh peneliti yaitu Direktur RSUD Dr. RM. Djoelham Binjai berkaitan dengan pelaksana program:

"Dalam implementasi PPK-BLUD di RSUD Dr. RM. Djoelham pelaksana utama kebijakan ini adalah bagian keuangan dan bagian anggaran program dibawah koordinasi wakil direktur keuangan. Bagian dan bidang yang lain juga ikut membantu dalam implementasi PPK-BLUD di RSUD Djoelham Binjai. (Informasi dari Direktur RSUD Dr. RM. Djoelham Binjai)

Hal tersebut juga dinyatakan oleh informan lainnya terkait pelaksana program implementasi yaitu:

"Kami merupakan garda terdepan dalam melaksanakan PPK-BLUD di RSUD Dr. RM. Djoelham binjai ini, bagian keuangan dan anggaran program yang berada dibawah koordinasi saya menjadi motor penggeraknya. Dari awal kamilah yang mepersiapkan segala sesuatu yang dibutuhkan untuk melaksanakan kebijakan ini. Tentunya kami juga tidak bisa bekerja sendiri tanpa bantuan dari bagian dan bidang lain yang secara langsung maupun tidak langsung juga sangat membanu melaksanakan kebijakan PPK-BLUD di RSUD Djoelham ini. (Informasi dari Wakil Direktur Keuangan RSUD Dr. RM. Djoelham Binjai)

Jadi dalam hal ini dapat disimpulkan bahwa pelaksana program suatu kebijakan harus saling bekerjasama dalam mensukseskan implementasi suatu kebijakan. Baik yang terlibat secara langsung mauun tidak langsung. Stakeholders kebijakan terdiri dari aktor aktor kebijakan yang berperan sejak proses formulasi, implementasi dan evaluasi 
kebijakan. Para aktor dapat dibedakan menjadi aktor internal birokrasi dan aktor eksternal birokrasi (Anderson dalam Muhlis Madani, 2011:36)

Keterkaitan Implementasi PPK-BLUD di RSUD Dr. RM Djoelham Binjai dengan Sumber-Sumber Daya yang Digunakan

Dari hasil observasi peneliti di lapangan apanila dilihat dari sisi sumber dana, RSUD Dr. Djoelham Binjai menyiapkan anggaran untuk persiapan implementasi PPK-BLUD. Anggaran yang disiapkan diperuntukkan untuk panitia yang dibentuk agar dapat bekerja secara optimal. Selain anggaran untuk keperluan internal tim yang dibentuk seperti alat tulis kantor, perlengkapan dan peralatan kantor, honorarium tim, juga disiapkan anggaran bimbingan dan pelatihan mengenai BLUD dan anggaran untuk melakukan studi banding ke rumah sakit lain yang telah lebih dahulu menerapkan PPK-BLUD di rumah sakitnya.

Selanjutnya peneliti melakukan wawancara dengan informan kunci terkait sumber daya yang ada dalam implementasi PPK-BLUD di RSUD Dr. Djoelham Kota Binjai, yaitu:

"Dari sisi sumber daya, terutama sumber daya manusia dalam implementasi PPK-BLUD di RSUD Djoelham. Selain membentuk tim yang diisi oleh orang - orang dari internal rumah sakit yang dianggap kompeten, kita juga mendapatkan bantuan dan bimbingan dari Badan Pemeriksa Keuangan dan Pembangunan (BPKP) perwakilan Provinsi Sumatera Utara. BPKP perwakilan Sumatera Utara telah beberapa kali melakukan bimbingan dan pendampingan ke beberapa rumah sakit di Sumatera Utara (Informasi dari Direktur RSUD Dr. RM. Djoelham)

Informan lain yang diwawancarai peneliti juga mengungkapkan perihal sumber daya yang ada pada saat proses implementasi PPKBLUD Di RS. Djoelham Binjai, yaitu:

"Dengan dibentuknya tim persiapan penerapan PPK-BLUD di RSUD Dr. Djoelham Binjai, maka orang - orang yang ada dalam tim tersebut merupakan orang - orang yang dianggap mampu dan memiliki kompetensi. Tim tersebut terdiri dari lintas bagian dan bidang yang ada walaupun sebagian besar diambil dari bagian keuangan dan anggaran program. Hal ini dikarenakan lebih banyak hal - hal yang perlu dipersiapkan dari bagian keuangan dan bagian anggaran program. Selain pembentukan tim, kita juga mempersiapkan anggaran yang memadai untuk menopang segala kebutuhan tim yang bertugas mempersiapkan implementasi BLUD di rumah sakit ini.". (Informasi dari Kepala Bagian Anggaran dan Program).

Dapat dilihat bahwa dari sumber daya yang digunakan, dapat dilihat bahwa persiapan implementasi BLUD di RSUD Djoelham menggunakan sumber daya yang ada dengan mendapat bimbingan dan pendampingan dari BPKP perwakilan Sumatera Utara. Tim yang bertugas juga mengikuti bimbingan teknis dari lembaga pelatihan yang mengadakan pelatihan tentang BLUD dan melakukan Studi banding ke rumah sakit yang telah menerapkan PPK-BLUD. Sumber dana yang digunakan adalah anggaran rumah sakit yang bersumber dari APBD Kota Binjai.

Konteks Kebijakan (Context Of Policy). Konteks kebijakan juga merupakan bagian penting yang perlu diperhatikan selain dari isi kebijakan yang terkait dengan pelaksanaan kebijakan, pada pengimplementasian kebijakan sebaiknya dapat mengetahui variabel - variabel yang mengakibatkan suatu kebijakan berhasil atau gagal dimplementasikan. Konteks kebijakan merupakan variabel yang bisa mempengaruhi keberhasilan suatu implementasi kebijakan termasuk juga pada implementasi Pola Pengelolaan Keuangan Badan Layanan Umum Daerah (PPK-BLUD). Berikut ini adalah pemaparan mengenai konteks kebijakan pada pelaksanaan PPK-BLUD di RSUD Dr. RM Djoelham Binjai.

Keterkaitan Implementasi PPK-BLUD di RSUD Dr. RM. Djoelham Binjai dengan Kekuasaan, Kepentingan-Kepentingan dan Program atau Strategi dari Aktor yang Terlibat.

Berbicara mengenai strategi, Direktur RSUD selaku penanggungjawab implementasi PPK-BLUD di RSUD Djoelham Binjai mengambil langkah - langkah strategis guna mempercepat pelaksanaan BLUD di RSUD Djoelham Binjai. Hal ini seperti yang diungkapkan pada saat wawancara mengenai strategi dan aktor yang terlibat, yaitu:

"Setelah dibentuk tim persiapan implementasi BLUD di RSUD Djoelham, kita langsung mengadakan rapat dan menbagi tim 
tersebut menjadi kelompok - kelompok kecil yang bertanggungjawab menyelesaikan tugasnya masing - masing. Ada yang mengerjakan Rencana Strategi Bisnis (RSB), ada yang mengerjakan Standart Pelayanan Minimal (SPM), ada yang mengerjakan pola tata kelola. Jadi kelompok - kelompok kecil ini diberi target untuk menyelesaikan dokumen yang menjadi tanggungjawabnya. Dengan demikian kita bisa mempercepat proses penyelesaian persyaratan yang dibutuhkan sesuai target yang telah direncanakan. Setelah penilaian yang dilakukan oleh tim penilai yang diketuai oleh bapak Sekretaris Daerah yang hasilnya penilaiannya kita dianggap layak menerapkan PPK-BLUD. Kita terus bergerak cepat untuk mengimplementasikan BLUD di RS Djoelham, hal yang paling dasar adalah membuat Rencana Bisnis Anggaran (RBA) yang berdampingan dengan Rencana Kerja Anggaran (RKA). Sehingga implementasi PPK-BLUD di RSUD Djoelham dapat segera dilaksanakan tepatnya dimulai pada 1 januari 2016 (Informasi dari Direktur RSUD Dr. RM. Djoelham Binjai)

Hal ini juga dikuatkan oleh informan lainnya seperti hasil wawancara yang dilakukan peneliti tentang bagaimana tanggapan dan strategi yang dilakukan dalam menjalankan program PPK-BLUD di RSUD RM. Djoelham Binjai, yaitu:

"Setelah penetapan PPK-BLUD di RSUD Djoelham dengan dikeluarkannya Surat Keputusan Bapak Walikota Nomor : 900580/K/Tahun 2015 tentang penetapan Badan Layanan Umum Daerah RSUD Dr. RM. Djoelham Binjai, kita langsung bergerak mepersiapkan dokumen - dokumen pendukung lainnya dan seiiring dengan itu kita juga mengadakan sosialisasi dengan pihak - pihak terkait dengan implementasi BLUD baik di internal rumah sakit juga dengan pihak eksternal seperti Badan Pengelola Keuangan Kota Binjai dan Inspektorat Kota Binjai. Diawal penerapannya memang ditemui beberapa kendala, terutama mengenai penganggaran dan pelaporan keuangan, hal ini merupakan sesuatu yang biasa terjadi karena program ini adalah program baru yang perlu pemahaman dan sosialisasi yang lebih optimal lagi". ((Informasi dari Kepala Bagian Anggaran dan Program)

Dengan penerapan PPK-BLUD yang merupakan hal baru dalam pola pengeloaan rumah sakit, tentunya dalam pelaksanaannya menemui berbagai kendala. Oleh karena itu dibutuhkan strategi - strategi yang baik sehingga kendala yang ada dapat diminimalisir. Disinilah dibutuhkan aktor - aktor pelaksana kebijakan yang handal dalam melaksanakan strategi yang direncanakan. Dalam pemilihan aktor - aktor yang berperan menjalankan strategi pelaksanaan kebijakan tersebut. Menurut Jones (dalam Silalahi, 1992 : 150 ) dalam membahas implementasi kebijakan terdapat aktor yang terlibat, yaitu : Beberapa orang diluar birokrat - birokrat yang mungkin terlibat dalam aktivitas - aktivitas implementasi suatu kebijakan.

\section{Keterkaitan Implementasi PPK-BLUD di RSUD Dr. RM Djoelham Binjai dengan Karakteristik Lembaga dan Rezim yang Berkuasa}

Dalam implementasi suatu kebijakan, karakteristik lembaga dan rezim yang berkuasa juga ikut berperan. Pada bagian ini peneliti akan membahas bagaimana situasi dan kondisi pihak-pihak yang terkait. Apakah telah sesuai dengan tugas pokok dan fungsinya dalam melaksanakan tugasnya. Dengan demikian dapat kita lihat sejauh mana peranan rezim yang sedang berkuasa dan karakteristik lembaga dalam implementasi PPK-BLUD di RSUD Djoelham Kota Binjai.

Hal tersebut seperti yang dikemukakan pada saat wawancara yang dilakukan kepada direktur sebagai berikut :

$$
\text { "sebagai pimpinan saya yang }
$$

bertanggungjawab dalam implementasi PPKBLUD di RSUD Djoelham ini. Hal ini juga sesuai dengan Tugas Pokok dan Fungsi RSUD Dr. R.M. Djoelham Binjai. RSUD memiliki tugas pokok membantu Walikota dalam melaksanakan penyusunan dan pelaksanaan kebijakan daerah di bidang pelayanan kesehatan. Fungsi RSUD adalah perumusan kebijakan teknis bidang pelayanan kesehatan, pemberian dukungan atas penyelenggaraan Pemerintah Daerah di bidang pelayanan kesehatan, dan pelaksanaan tugas lain yang diberikan oleh Walikota sesuai tugas dan fungsinya. Hal ini juga sesuai dengan arahan dari Bapak walikota bahwa beliau akan selalu mendukung apapun program yang ingin dilaksanakan oleh rumah sakit yang bertujuan untuk meningkatkan mutu pelayanan. Oleh karena itu dengan ditetapkan RSUD Djoelham sebagai Badan Layanan Umum Daerah, kita berupaya sekuat tenaga melaksanakan kebijakan tersebut untuk mencapai tujuan 
bersama yaitu meningkatkan mutu pelayanan rumah sakit milik Pemerintah Kota Binjai ini". (Informasi dari Direktur RSUD Dr. RM Djoelham Binjai)

Direktur rumah sakit sebagaimana yang telah diamanahkan oleh Bapak Walikota Binjai harus terus mengkoordinir dan memimpin jalannya program PPK-BLUD di RSUD Dr. RM Djoelham Binjai. Komitmen dari Bapak Walikota dalam mendukung pelaksanaan PPk-BLUD juga sangat mendukung implementasi PPK-BLUD di RSUD Djoelham Binjai. Walikota Binjai betul - betul mendukung program ini bukan hanya dari sisi anggaran, juga sering turun langsung memantau implementasi PPK-BLUD di rumah sakit.

Keterkaitan Implementasi PPK-BLUD di RSUD Dr. RM Djoelham Binjai dengan Tingkat Kepatuhan dan Adanya Respon dari Para Pelaksana

Pada variabel kebijakan ini, variabel tingkat kepatuhan dan respon dari para implementor suatu kebijakan adalah hal yang juga penting dengan menentukan siapa pelaksananya, karena tingkat kepatuhan dan adanya daya tanggap dari para pelaksana program adalah bentuk dukungan yang tentunya juga mempengaruhi keberhasilan implementasi suatu kebijakan.

Dalam hasil wawancara peneliti dengan salah satu informan, dikemukakan perihal kepatuhan dan respon dari pelaksana yaitu :

"Pada awal penerapan PPK-BLUD, tentunya belum sepenuhnya dapat berjalan seperti yang diharapkan. Keinginan kita, setiap pihak yang memiliki tanggungjawab dalam implementasi kebijakan ini dapat bersinergi dalam rangka mempercepat penerapannya dilapangan. Namun mungkin karena PPK-BLUD ini identik hanya dengan pengelolaan keuangannya. Bagian dan bidang lain yang tidak dberada dibawah koordinasi saya, merasa tidak terlalu berkepentingan dengan PPK-BLUD ini. Padahal selain pengelolaan keuangan, dalam syarat implementasinya disyaratkan juga standard pelayanan minimal dan pola tata kelola yang tentunya harus melibatkan bagian dan bidang lain di rumah sakit ini.". (Informasi dari wakil direktur keuangan RSUD Dr. RM. Djoelham Binjai)

Dapat dilihat dari sisi kepatuhan para pelaksana program belum optimal dalam mendukung implemantasi PPK-BLUD di RSUD Dr. RM. Djoelham terutama bagian dan bidang yang tidak berada dibawah koordinasi keuangan dan anggaran program.

\section{SIMPULAN}

Pada awal persiapan implementasi PPKBLUD di RSUD Dr. RM Djoelham Kota Binjai, tim persiapan yang dibentuk menghadapi berbagai tantangan. Dikarenakan PPK-BLUD ini merupakan kebijakan baru ini perlu sosialisasi yang memadai kepada seluruh kelompok kepentingan yang terkait dan berkepentingan dengan RSUD Dr. RM. Djoelham Binjai. Setelah penerapan PPK-BLUD di RSUD Dr. RM. Djoelham Binjai, dapat menunjukkan suatu perubahan yang sebelumnya proses pengelolaan anggaran, keuangan, dan pelaporan yang selama ini murni harus berdasarkan peraturan keuangan dengan mekanisme APBD. Namun dengan penerapan PPK-BLUD, seluruh pendapatan yang peroleh RSUD Djoelham dapat langsung dikelola dan dipergunakan untuk kebutuhan dan keperluan RSUD. Sehingga diharapkan dapat memperingkas birokrasi khususnya keuangan sehingga pada akhirnya dapat meningkatkan mutu pelayanan Rumah Sakit. Dalam pelaksanannya masih terdapat beberapa kendala yang dihadapi terutama pemahaman bagian dan bidang lain tentang PPK-BLUD yang ada di RSUD Djoelham Binjai sehingga dibutuhkan koordinasi yang baik antar bagian dan bidang.

\section{DAFTAR PUSTAKA}

Dwiyanto, A. (2018). Manajemen Pelayanan Publik: Peduli Inklusif Dan Kolaborasi. Yogyakarta: Gajah Mada University Press.

Moleong, L.J. (2007). Metodologi Penelitian Kualitatif. Bandung: PT. Remaja Rosdakarya Offset.

Madani, M. (2011). Dimensi interaksi aktor dalam proses perumusan kebijakan publik. Jakarta: Graha Ilmu.

Saggaf, S., (2018), Reformasi Publik di Negara Berkembang. Makassar: CV. Sah Media

Subarsono, A.G. (2009). Analisis Kebijakan Publik, Konsep, Teori dan Aplikasi. Jakarta. Pustaka Pelajar.

Winarno, B. (2002). Teori dan Proses Kebijakan Publik. Yogyakarta: Mediapressindo.

Waluyo. (2002). Manajemen publik: konsep, aplikasi, dan implementasinya dalam pelaksanaan otonomi daerah. Indonesia: Mandar Maju. 
Bambang Azis Silalahi, Marlon Sihombing \& Isnaini, Analisis Implementasi Pola Pengelolaan Keuangan

Republik Indonesia. Peraturan Pemerintah Republik Indonesia Nomor 23 Tahun 2005. Pengelolaan Keuangan Badan Layanan Umum.

Republik Indonesia. Peraturan Pemerintah Republik Indonesia Nomor 25 Tahun 2005. Standar Pelayan Minimal.

Republik Indonesia. Undang-Undang Republik Indonesia Nomor 1 Tahun 2004. Perbendaharaan Negara.

Republik Indonesia. Undang-Undang Republik Indonesia Nomor 14 Tahun 2008. Keterbukaan Informasi Publik.

Republik Indonesia. Undang-Undang Republik Indonesia Nomor 36 Tahun 2009. Kesehatan.

Republik Indonesia. Undang-Undang Republik Indonesia Nomor 44 Tahun 2009. Rumah Sakit.

Sembiring, B., Isnaini, I., \& Leviza, J. (2021). Pengawasan Otoritas Jasa Keuangan terhadap Pelaku Usaha Pegadaian Illegal. Journal of Education, Humaniora and Social Sciences (JEHSS), 4(2), 1129-1135. doi:https://doi.org/10.34007/jehss.v4i2.85 0

Lumbantoruan, R., Agustin, S., Susanti, S., \& Sari, I. (2021). Pengaruh Profitabilitas, Kinerja Keuangan, Ukuran Perusahaan dan Solvabilitas terhadap Pertumbuhan Laba. Journal of Education, Humaniora and Social Sciences (JEHSS), 4(1), 442-449. doi:https://doi.org/10.34007/jehss.v4i1.67 4

Sitohang, A., \& Wulandari, B. (2020). Pengaruh Current Ratio, Debt To Equity Ratio, Earning
Per Share, terhadap Kinerja Keuangan. Journal of Education, Humaniora and Social Sciences (JEHSS), 3(2), 577-585. doi:https://doi.org/10.34007/jehss.v3i2.36 1

Poedjianto, A., Warjio, W., \& Isnaini, I. (2019). Evaluasi Penatausahaan Barang Milik Daerah di Badan Pengelolaan Keuangan Kabupaten Aceh Singkil. Strukturasi: Jurnal Ilmiah Magister Administrasi Publik, 1(1), 43-51.

Silalahi, B., Sihombing, M., \& Isnaini, I. (2021). Analisis Implementasi Pola Pengelolaan Keuangan Badan Layanan Umum Daerah (BLUD) Pada Rumah Sakit Umum Daerah (RSUD) Dr. RM. Djoelham Binjai. Strukturasi: Jurnal Ilmiah Magister Administrasi Publik, $3(1)$, 1-13. doi:https://doi.org/10.31289/strukturasi.v3 i1.518

Ketike, R., Harahap, R., \& Siregar, N. (2021). Analisis Kinerja Dinas Pengelolaan Keuangan Daerah Di Bidang Pendapatan Pada Kabupaten Gayo Lues. Strukturasi: Jurnal Ilmiah Magister Administrasi Publik, 3(1), 99-117. doi:https://doi.org/10.31289/strukturasi.v3 i1.726

Hakim, M., Kusmanto, H., \& Isnaini, I. (2019). Implementasi Kebijakan Peraturan Kepala Badan Pengawasan Keuangan dan Pembangunan Republik Indonesia Nomor 6 Tahun 2015. Strukturasi: Jurnal Ilmiah Magister Administrasi Publik, 1(2), 131-137 